\title{
PENGENALAN APLIKASI ANDROID SEBAGAI BAHAN BANTU PENGAJARAN MATA PELAJARAN KIMIA SMA
}

\author{
Muhammad Zulfadhilah'1), Nur Hidayah ${ }^{1)}$ \\ 1)Program Studi Teknologi Informasi, Fakultas Sains dan Teknologi, Universitas Sari Mulia, Banjarmasin, Kalimantan Selatan, \\ Indonesia \\ Corresponding author :Muhammad Zulfadhilah \\ E-mail :zulfadhilah@unism.ac.id
}

Diterima 13 Agustus 2020, Direvisi 12 Oktober 2020, Disetujui 15 Oktober 2020

\begin{abstract}
ABSTRAK
Pengabdian masyarakat yang dilakukan pada beberapa sekolah menengah atas di daerah Banjarmasin ini bertujuan untuk mengenalkan pemanfaatan teknologi sebagai media pembelajaran.Pengabdian ini berfokus pada pemanfaatan teknologi berbasis perangkat lunak Android pada ponsel siswa sekolah menengah atas di daerah Banjarmasin untuk digunakan sebagai media belajar. Sehingga pelajar tidak merasa jenuh saat melakukan aktivitas pembelajaran. Berdasarkan observasi dan pembagian angket pada 34 siswa di 5 sekolah menengah atas daerah Banjarmasin didapatkan bahwa lebih dari $80 \%$ siswa-siswa di sekolah menengah atas masih menggunakan media konvensional dalam memahami sebuah materi pelajaran. Selain itu penggunaan teknologi dalam memahami materi pembelajaran didapatkan siswa dari internet dan hanya sedikit yang mengetahui bahwa sudah ada aplikasi-aplikasi berbasis android yang bisa digunakan sebagai salah satu media pembelajaran. Hal ini menjadi salah satu faktor pendorong rendahnya minat anak untuk belajar sehingga ada anggapan jika mata pelajaran tertentu sangat sulit dipahami, terutama mata pelajaran berbasis sains. Salah satu solusi yang coba ditawarkan adalah penggunaan aplikasi berbasis android sebagai media pembelajar. Hal ini ditunjang dengan gaya keseharian pelajar zaman sekarang yang tidak terlepas dari penggunaan gawai. Sosialisasi penggunaan aplikasi kepada siswa sekolah menengah atas menunjukkan hasil yang positif, dimana siswa merasa terbantu untuk memahami materi pembalajaran. Hal ini dapat dilihat dari respon pengisisan kuosiener setelah pengenalan aplikasi, dimana lebih dari 95\% responden merasa lebih mudah memahami materi dengan adanya aplikasi android.
\end{abstract}

Kata kunci:pendidikan; perangkat lunak; teknologi.

\begin{abstract}
This community service which was carried out at several senior high schools in the Banjarmasin area aims to introduce the use of technology as a learning medium. This service focuses on the use of Android software-based technology on the mobile phones of high school students in the Banjarmasin area to be used as learning media. So that students do not feel bored when doing learning activities. Based on observations and questionnaires distribution to 34 students in 5 high schools in the Banjarmasin area, it was found that more than $80 \%$ of students in high schools still used conventional media in understanding a subject matter. In addition, the use of technology in understanding learning material is obtained by students from the internet and only a few know that there are Android-based applications that can be used as a learning medium. This is one of the factors driving children's low interest in learning so that there is an assumption that certain subjects are very difficult to understand, especially science-based subjects. One solution that is being offered is the use of Android-based applications as a learning medium. This is supported by the daily style of students today which cannot be separated from the use of gadgets. The socialization of the use of the application to high school students shows positive results, where students find it helpful to understand the learning material. This can be seen from the response to filling in the questionnaire after the introduction of the application, where more than $95 \%$ of respondents find it easier to understand the material with the android application.
\end{abstract}

Keywords: education; software; technology.

\section{PENDAHULUAN}

Mason R. berpendapat bahwa proses pendidikan pada masa yang akan datang ditentukan oleh jaringan informasi sehingga memungkinkan interaksi dan kolaborasi. Tony Bates menyatakan bahwa teknologi dapat meningkatkan kualitas dan jangkauan bila digunakan secara bijak dalam Pendidikan dan 
latihan. Alisjahbana juga mengemukakan bahwa pendekatan Pendidikan dan pelatihan nantinya akan bersifat just on time. Teknik pengajaran baru akan bersifat dua arah, yaitu kolaboratif dan interdisipliner.

Perkembangan zaman dan teknologi menuntut manusia untuk selalu berkembang, hal ini juga terjadi pada bidang pendidikan. Perkembangan teknologi informasi ini merupakan sebuah tuntutan dan usaha dalam peningkatan mutu pendidikan pada umumnya dan peningkatan sistem pembelajaran dewasa ini.

Edi Ismanto mengemukakan bahwa Smartphone merupakan perangkat seluler yang dilengkapi dengan sistem operasi seperti halnya sebuah komputer. Smartphone dapat mengimplementasikan berbagai bentuk multimedia dengan kemampuan memiliki mobilitas yang tinggi dan dapat dioperasikan secara lebih efektif .

Beberapa penelitian yang telah dilakukan diantaranya seperti Learning Chemistry Through Puzzle Based Game:Atom to Molecule yang bertujuan untuk menerapkan konsep dasar ilmu kimia seperti ikatan atom dan molekul dalam pembentukan obligasi pada permainan puzzle. Pemanfaatan Internet bisa meningkatkan prestasi belajar dengan mengakses situs-situs yang dapat menambah wawasan mereka. Penelitian lain oleh Betti dkk mengatakan bahwa penetrasi penggunaan perangkat mobile siswa sekolah menengah atas sangatlah besar. Selain itu, penelitian yang dilakukan oleh Umar Abdul Labib dan Berti Yolida pada tahun 2019 menyebutkan bahwa karakteristik media pembelajaran berbasis Android lebih mudah digunakan karena tidak memerlukan ruangan tertentu.

Menurut Joko Kuswanto dan Ferri Radiansah dalam penelitiannya menyebutkan bahawa kelebihan dari media pembelajaran berbasis android ini adalah sebagai berikut :

1) Mudah digunakan, menarik, dan simple

2) Belajar bisa dimana saja

3) Belajar secara offline atau tidak terhubung ke internet.

Berdasarkan dari hasil observasi pada 5 sekolah menengah atas di daerah Banjarmasin didapatkan bawah $88 \%$ siswa masih menggunakan media cetak sebagai literatur dan $12 \%$ lainnya sudah menggunakan media non-cetak, pada pertanyaan terkait penggunaan aplikasi Android sebagai media pembelajaran sekitar 35\% sedangkan $65 \%$ lainnya tidak menggunakan aplikasi Android sebagai media.
Media Pembelajaran

- Media Cetak - Media Non Cetak

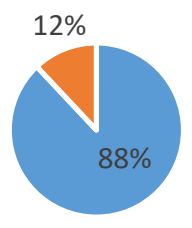

Gambar 1. Persentase Penggunaan Media Pembelajaran

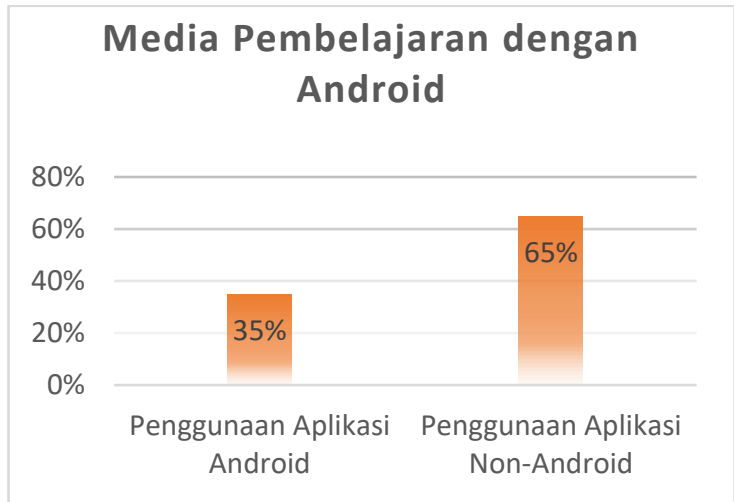

Gambar 2. Persentase Penggunaan Aplikasi Android

Tujuan dari kegiatan pengabdian masyarakat ini adalah dengan menggunakan ponsel pintar bisa menjadi salah satu inovasi pembelajaran pada siswa sekolah menengah atas di daerah Banjarmasin. Pembelajaran dengan memanfaatkan aplikasi android diharapkan dapat menumbuhkan semangat siswa untuk belajar. Hal ini didorong dengan kebiasaan anak yang susah terlepas dari penggunaan gaawai. Selanjutnya diharapkan aplikasi android untuk media pembelajaran dapat meningkatkan motivasi belajar siswa dan menghilangkan stigma pelajaran kimia sebagai mata pelajaran yang susah.

\section{METODE}

Kegiatan Pengabdian Masyarakat ini dilakukan oleh dosen Universitas Sari Mulia, sasaran kegiatan ini adalah siswa sekolah menengah atas sederajat di daerah Banjarmasin. Pengabdian ini dilakukan dalam bentuk sosialisasi untuk meningkatkan pengetahuan dan pemanfaatan teknologi informasi khususnya pada pemanfaatan smartphone berbasis Android di lingkungan sekolah menengah atas. Siswa sekolah menengah atas yang mengikuti kegiatan pengabdian kepada masyarakat ini adalah sebanyak 34 orang siswa dengan 5 guru yang terlibat dalam pendampingan kegiatan. 
Kegiatan dilakukan dengan pembagian kuesioner sebanyak 2 kali kepada peserta, pembagian kuesioner pertama dilakukan saat melakukan observasi ke sekolah yang mana peserta belum mendapatkan sosialisasi media pembelajaran dengan menggunakan aplikasi Android, kemudian pembagian kedua dilakukan saat peserta sudah mendapatkan sosisalisasi media pembelajaran aplikasi Android. Dari dua hasil kuesioner tersebut maka dilakukan perbandingan dalam mencari hasil akhir dari kegiatan ini.

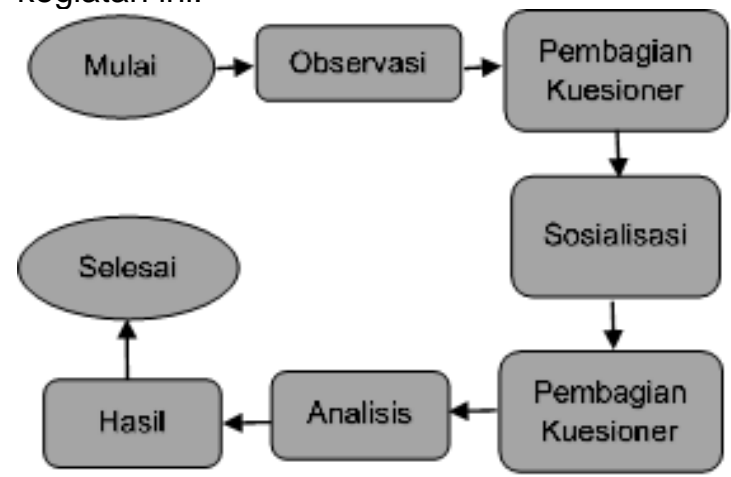

Gambar 3 Tahapan Pelaksanaan

Adapun tahapan pelaksaan kegitaan ini meliputi: 1) Observasi dengan melakukan kunjungan ke 5 SMA Negeri di Banjarmasin untuk mengetahui siswa sasaran yang akan dituju. 2) Pembagian Kuesioner sebelum melakukan sosialisasi. 3) Melakukan kegiatan sosialisasi pengenalan aplikasi Android untuk pembelajaran senyawa dan ikatan kimia. 4) Pembagian Kuesioner sesudah melakukan sosialisasi. 5) Analisis data dengan melakukan perbandingan hasil kuisoner yang dibagikan sebelum dan setelah pemaparan materi. 6) Hasil dari perbandingan kuesioner.

\section{HASIL DAN PEMBAHASAN}

Kegiatan pengabdian kepada masyarakat dilakukan dengan sosialisasi tatap muka kepada siswa-siswa sekolah menengah atas kelas X dan XI. Pada pemaparan kepada siswa, kami memberikan salah satu contoh aplikasi hasil dari penelitian sebagai salah satu inovasi pembelajaran dengan media smartphone.

Pada Gambar 1 dapat dilihat proses penyampaian materi dan praktek langsung penggunaan aplikasi dalam pelaksanaan kegiatan sosialisasi tentang penggunaan pemanfaatan teknologi informasi dalam proses pembelajaran. Proses pemaparan yang dilakukan meliputi pemberian materi dan praktek langsung cara penggunaan aplikasi.
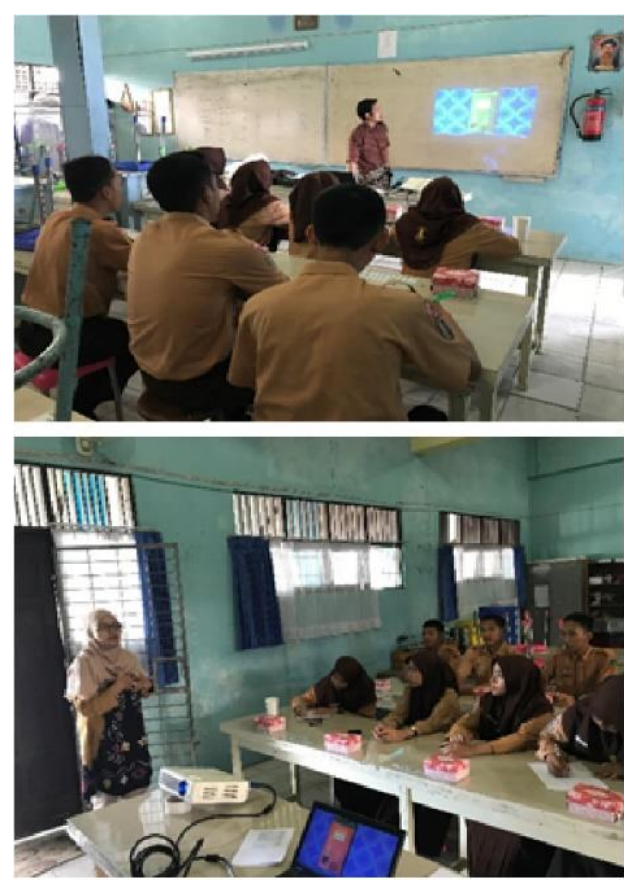

Gambar 4. Sosialisasi Kegiatan di SMA.

Aplikasi yang digunakan berfokus pada mata pelajaran kimia dasar tingkat sekolah menengah atas. Khususnya mengenai materi pengenalan unsur dan senyawa kimia serta ikatan yang terjadi pada senyawa kimia. Materi ini biasanya diberikan kepada siswa kelas $X$ dan IX Sekolah Menengah Atas. Perbedaan penggunaan kurikulum disekolah menyebabkan adanya perbedaan waktu pemberian materi sehingga ada sekolah yang siswanya mendapat materi tersebut pada kelas $\mathrm{X}$ dan ada yang diberikan pada saat kelas XI.

Untuk melihat sejauh mana aplikasi dapat membantu proses pembelajaran siswa, maka setelah siswa mencoba aplikasi yang disampaikan, kami memberikan kuesioner untuk pengisian terkait kebermanfaatan aplikasi tersebut dalam menunjang pembelajaran. Berdasarkan hasil kuisioner yang dibagikan sebelum dan sesudah pemaparan materi, pengunaan aplikasi android sebagai media pembalajaran memberikan manfaat yang sangat besar dalam proses pembelajaran. Siswa menjadi lebih mudah memahami materi dengan adanya tampilan visual yang menarik dari aplikasi. Aplikasi berbasis android yang digunakan juga mempermudah siswa untuk lebih fleksibel dari segi waktu untuk melakukan pembelajaran, karena hanya memerlukan kuota internet untuk mengakses aplikasi dan dapat dilakukan dimana saja.

\section{SIMPULAN DAN SARAN}

Berdasarkan kegiatan pengabdian kepada masyarakat ini dapat disimpulkan bahwa kegiatan ini berjalan dengan lancar, baik siswa ataupun guru pendamping ketika 
pelaksanaan terlihat antusias terhadap pemaparan tentang pemanfaatan teknologi informasi dalam bidang pendidikan. Kegiatan Pengabdian Masyarakat ini diharapkan bisa memberikan inovasi dalam bidang pembelajaran dengan media daring ataupun aplikasi pada smartphone berbasis Android.

Diharapkan pada kegiatan pengabdian kepada masyarakat selanjutnya para pengabdi akan bisa melakukan pendampingan untuk siswa sekolah tentang pembuatan media pembelajaran seperti aplikasi berbasis smartphone atau media pembelajaran lainnya.

\section{UCAPAN TERIMAKASIH}

Tim dosen mengucapkan terima kasih kepada LPPM Universitas Sari Mulia dan juga kepada sekolah yang telah kami kunjungi sehingga dapat terlaksananya pengabdian ini.

\section{DAFTAR RUJUKAN}

Agarwal, M., \& Saha, S. (2011). Learning chemistry through puzzle based game: Atoms to Molecule. ICETA 2011 - 9th IEEE International Conference on Emerging ELearning Technologies and Applications, Proceedings, 189-193. https://doi.org/10.1109/ICETA.2011.61 12613

Andiani, T. (2015). Sistem Pembelajaran Berbasis Teknologi Informasi dan Komunikasi. Sosial Budaya: Media Komunikasi IImu-IImu Sosial Dan Budaya, 12(1).

B.Ses, E. Polonia, dkk. (2015). Pemanfaatan Aplikasi Mobile Berbasis Android dalam Pembelajaran Fisika SMA. Seminar Nasional Fisika Dan Pembelajarannya 2015 (95).

Ismanto, Edi, dkk. (2017). Pemanfaatan Smartphone Android Sebagai Media Pembelajaran Bagi Guru Sma Negeri 2 Kota Pekanbaru. Jurnal Pengabdian UntukMu NegeRI, 1(1), 42. 10.37859/jpumri.v1i1.33.

Kuswanto, Joko \& Radiansyah, Ferri. (2018). Media Pembelajaran Berbasis Android Pada Mata Pelajaran Sistem Operasi Jaringan Kelas XI. Jurnal Media Infotama, 14(1), 15-20.

Listiani, L., \& Kusuma, A. E. (2017). Memperkenalkan Penerapan Strategi Pembelajaran dengan Pendekatan Saintifik Kepada Guru Sekolah Dasar Melalui Pelatihan Singkat. Jurnal Pengabdian Masyarakat Borneo, 1(1), 1.

https://doi.org/10.35334/jpmb.v1i1.235

Nurmala. (2019). Pemanfaatan Internet sebagai Media E-Learning untuk Siswa dan
Guru SMPN 3 Tarakan. Jurnal Pengabdian Masyarakat Borneo, 2(2), 21.

https://doi.org/10.35334/jpmb.v2i2.518

Sutabri, T. (2014). Pengantar Teknologi Informasi (A. Sahala \& S. Wibowo (eds.); 1st ed.). CV. Andi Offset.

U.Labib, \& B.Yolinda. (2019). Pengembangan Aplikasi berbasis Android yang Terintegrasi dengan Website sebagai Media Pembelajaran Biologi. Jurnal Bioterdidik, 7(5), 33-42.

Zulfadhilah, M., \& Hidayah, N. (2019). Aplikasi Penyusunan Ikatan Kimia Berbasis Android sebagai Media Pembelajaran. Jurnal Edik Informatika, 6(1), 37-41. https://doi.org/http://dx.doi.org/10.2220 2/ei.2019.v6i1.3690 